Original Research Paper

\title{
Phytochemical Contents of Underutilized Edible Plant from Riau Province, Ridan (Nephelium maingayi Hiern - Sapindaceae)
}

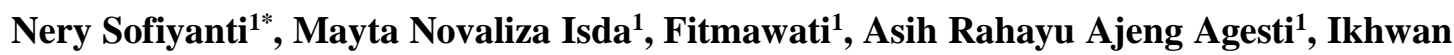 \\ Taufik $^{1}$, Maya Sari ${ }^{1}$, Syafroni Pranata ${ }^{2}$ \\ ${ }^{1}$ Department of Biology, Faculty of Math and Natural Resources Science, Universitas Riau. Kampus \\ Bina Widya, Km. 12.5, Panam, Pekanbaru, Riau, Indonesia. \\ ${ }^{2}$ Ecology Division, Generasi Biologi Indonesia (Genbinesia) Foundation, Jl. Swadaya Barat No. 4 \\ Gresik Regency 61171, East Java, Indonesia
}

Article History
Received : March $23^{\text {th }}, 2021$
Revised : April $04^{\text {th }}, 2021$
Accepted : April $22^{\text {th }}, 2021$
Published : May $03^{\text {th }}, 2021$
*Corresponding Author: $_{\text {Nery Sofiyanti }}$
Department of Biology, Faculty of
Math and Natural Resources
Science, Universitas Riau.
Pekanbaru, Riau, Indonesia
Email:
nery.sofiyanti@lecturer.unri.ac.id.

\begin{abstract}
Ridan (Nephelium maingayi) is one of Nephelium (Sapindaceae) member distributed in Riau Province. This underutilized edible plant is commonly found as wild species, and poses three different fruit morphologies (oval, asymmetric and rounded shaped fruit). The phytochemical contents of these fruit species had not been reported. This study aimed to identify the phytochemical contents of fruit parts (peel, aril and seed) of three different fruit shapes of N. maingayi (oval, asymmetric and rounded shaped fruit) from Riau Province. A total of six secondary metabolite groups were tested (alkaloid, terpenoid, steroid, flavonoid, saponin dan tannin), using qualitative analysis based on the presence of precipitation (alkaloid), the change of mixture color (steroid, terpenoid, flavonoid and tannin) and soapy foaming substance for saponin. The result showed that peels of Ridan (N. maingayi) gave the highest phytochemical contents (alkaloid, terpenoid, flavonoid, saponin and tannin.). Terpenoid and saponin were found in peel, aril and seed of three different fruit shapes. This study concluded that the phytochemical contents of three fruit shapes of Ridan ( $N$. maingayi) varies among the different shapes of fruit. This result of this study provide the first information of bioactive profile of $N$. maingayi form Riau Province.
\end{abstract}

Keywords: Phytochemical Content, Secondary Metabolite, Riau, Ridan, Underutilized Fruit, Wild Nephelium.

\section{Introduction}

The study of phytochemical contents of Nephelium (Sapindaceae) members is very limited. The most common species that had been screened its secondary metabolite is Rambutan (Nephelium lappaceum) as reported many by scientists i.e. Halim et al. (2019), Nethaji et al. (2015), Kamlanathan et al. (2015) Muhtadi et al. (2017) and Sukmandari et al. (2017). Ridan (Nephelium maingayi Hiern) is one out of 25 Nephelium member). This species is characterized by its hairless peel, with small fruit (ca.1.2 - $2.2 \mathrm{~cm}$ length $\mathrm{x} 1-1.5 \mathrm{~cm}$ width). Most of the Nephelium members have long appendage that ressemble as "hair". Therefore, the local name of hairy fruit Nephelium is Rambutan (from "rambut" - hair). The fruit of $N$. maingayi has no long appendage and grouped as hairless Nephelium. The edible part of Ridan fruit is aril. However, due to its small and almost sour aril, this plant is rarely found as cultivated species at Riau Province but commonly found as wild species. Moreover, the stem has low economical value due to its small size. Therefore, $N$. maingayi is one of underutilized wild species in this province.

The color of fruit peel of Nephelium members, including Ridan are reddish yellow to blackish red. These color derived from the natural plant pigment such as lycopene (Kong et 
al. 2010), anthocyanin (Lian et al. 2011) or anthocyanin (Hock et al. 2017). The study of Lian et al. (2011) reported that anthocyanin is natural pigment of peel of $N$. lappaceum. During our previous exploration at Kuantan Singingi and Kampar District Riau Province, we observed that the peel fruit color of Ridan ( N. maingayi) varies from light red to dark red color, based on the shape of fruit. These colors indicate high phytochemical contents of peel of Ridan. A total of three different fruit shape are identified from Riau, i.e. ovale shaped fruit, asymmetric shaped fruit dan rounded shaped fruit. Every fruit shape has different peel color.

The phytochemical study of Nephelium species was commonly investigated on $N$. lappaceum, the most common Nephelium species. However, there is no report on phytochemical content of $N$. maingayi. The phytochemical profiling on plant is necessary in order to discover plant bioactive profile. This examined the health benefit of a plant species. Therefore, this study aimed to conduct phytochemical screening of the peel, aril and seed of Ridan (N. maingayi).

\section{Materials and Methods}

\section{Sample collection}

All of samples were collected from the field using exploration method. During the exploration we identified a total of three variations of fruit morphology, i.e. oval shaped fruit, asymmetric shaped fruit and rounded shaped fruit. Table 1 shows the specimens that examined in this study.

\section{Phytochemical screening}

The phytochemical screenings had been carried out on fruit peel, aril and seed of three different fruit shape of Nephelium maingayi (Table 1). The secondary metabolite groups observed in this study were alkaloid, terpenoid, steroid, flavonoid, saponin, and tannin. Table 2 presents the materials and methods of phytochemical screening, as well as the positive parameter of each secondary metabolite test. The result of phytochemical screenings was presented using symbol + (positive) and - (negative). The data were then tabulated and descriptively analysed.

\section{Result and Discussion}

In this study, phytochemical screening had been carried out from a total of 9 samples of Ridan (N. maingayi). It had been done using qualitative analysis based on the presence of precipitation (alkaloid), the change of mixture color (steroid, terpenoid, flavonoid and tannin) and soapy foaming substance for saponin. Figure 1,2 , and 3 show the phytochemical screening of each examined sample, indicated by the change of the mixture after being tested.

Based on the phytochemical result of three different fruit shapes of Ridan $(N$. maingayi) presented in Figure 1, 2 and 3, the phytochemical contents vary among the examined samples. Alkaloid was found in four out of nine samples, i.e. three extracts of fruit peel (oval shaped fruit, asymmetric shaped fruit and rounded shaped fruit) and one extract of seed (oval shaped fruit). The alkaloid content is indicated by the presence of red or orange precipitation. The peel extracts of oval shaped fruit (Fig.1.Ap), asymmetric shaped fruit (Fig 2.Ap) and rounded shaped fruit (Fig. 3.Ap) shows the precipitation at the bottom of test tube. Only seed extract of rounded shaped fruit of Ridan (Fig. 1.As) that indicates the presence of alkaloid. 
Table 1. List of examined specimen in this study

\begin{tabular}{|c|c|c|c|c|}
\hline No. & Fruit Characteristic & Organ & $\begin{array}{c}\text { Sample } \\
\text { Codes }\end{array}$ & Note \\
\hline \multirow[t]{3}{*}{ A. } & \multirow{3}{*}{$\begin{array}{l}\text { Oval shaped fruit: Oval fruit has the biggest size } \\
\text { among the other fruit, with ca. } 1.5 \mathrm{~cm} \text { long and } 1 \\
\mathrm{~cm} \text { wide, narrower toward base, tip rounded, fruit } \\
\text { base and tip are symmetric. The peel of this fruit } \\
\text { is light red }\end{array}$} & 1. Peel & 1 & \multirow{3}{*}{$\begin{array}{l}\text { Bangkinang Village, } \\
\text { Bangkinang, Kampar, } \\
\text { Riau Province }\end{array}$} \\
\hline & & 2. Aril & 2 & \\
\hline & & 3. Seed & 3 & \\
\hline \multirow[t]{3}{*}{ B. } & \multirow{3}{*}{$\begin{array}{l}\text { Asymmetric shaped fruit: asymmetric at the base } \\
\text { and tip of fruit, wider at the base, ca. } 1.2 \mathrm{~cm} \text {. The } \\
\text { peel is dark red peel. }\end{array}$} & 1. Peel & 4 & \multirow{3}{*}{$\begin{array}{l}\text { Tanjung Village, Hulu } \\
\text { Kuantan, Kuantan } \\
\text { Singingi, Riau Province }\end{array}$} \\
\hline & & 2. Aril & 5 & \\
\hline & & 3. Seed & 6 & \\
\hline \multirow[t]{3}{*}{ C. } & \multirow{3}{*}{$\begin{array}{l}\text { Rounded shaped fruit: fruit shape is rounded, ca. } \\
1 \mathrm{~cm} \text { in diameter, dark red peel }\end{array}$} & 1. Peel & 7 & \multirow{3}{*}{$\begin{array}{l}\text { Rumbio Jaya, Kampar, } \\
\text { Riau Province }\end{array}$} \\
\hline & & 2. Aril & 8 & \\
\hline & & 3. Seed & 9 & \\
\hline
\end{tabular}

Table 2. Methods and Parameters of Phytochemical screening

\begin{tabular}{|c|c|c|c|}
\hline No. & $\begin{array}{l}\text { Group of } \\
\text { secondary } \\
\text { metabolite }\end{array}$ & Materials and Methods & $\begin{array}{c}\text { Parameters of } \\
\text { Positive Result (+) }\end{array}$ \\
\hline 1 & Alkaloid & $\begin{array}{l}4 \text { gr of ground sample }+ \text { Chloroform }+10 \mathrm{ml} \text { ammoniac- } \\
\text { chloroform, filter. } 10 \text { filtrate drops }+\mathrm{H} 2 \mathrm{SO} 42 \mathrm{~N} \text {, mix well. } \\
3 \text { drops of upper layer + Dragendorff. }\end{array}$ & $\begin{array}{l}\text { Red, orange } \\
\text { precipitation }\end{array}$ \\
\hline 5 & Terpenoid & \multirow{2}{*}{$\begin{array}{l}50 \mathrm{mg} \text { of ground sample }+\mathrm{AAG} \text { incubate for } 15 \mathrm{~min}+3 \\
\text { drops } \mathrm{H}_{2} \mathrm{SO}_{4}\end{array}$} & Orange, purple \\
\hline 6 & Steroid & & Green to blue \\
\hline 2 & Flavonoid & $\begin{array}{l}200 \text { gr ground sample, }+5 \mathrm{ml} 70 \% \text { ethanol, heat for } 5 \\
\text { min }+3 \text { drops of absolute } \mathrm{HCL}+0.2 \mathrm{gr} \mathrm{mg} \text { powder. }\end{array}$ & $\begin{array}{l}\text { Yellow, orange to } \\
\text { dark red or magenta }\end{array}$ \\
\hline 3 & Saponin & $\begin{array}{l}2 \text { gr thin cut sample }+ \text { aquades, boiled } 2-3 \text { min. Shake } \\
\text { the mixture strongly. }\end{array}$ & $\begin{array}{l}\text { Soapy foaming } \\
\text { substance }\end{array}$ \\
\hline 4 & Tannin & $\begin{array}{l}20 \mathrm{mg} \text { thin cut sample }+70 \% \text {, ethanol. } 1 \mathrm{ml} \text { mixture }+2 \\
\text { drops of } 1 \% \mathrm{FeCL}_{3}\end{array}$ & Blueish dark, green \\
\hline
\end{tabular}

(References: Sangi et al. 2008; Deepa et al. 2014; Raman et al. 2018)

For terpenoid test, all of the samples contain this secondary metabolite, indicated by the presence of orange to purple coloration as seen in Fig. 1B, 2B and 3B. In contrast, there is no samples have steroid due to no green or blue coloration. All of the fruit parts (peel, aril and seed) from three different fruit shapes indicated the presence of terpenoid. Figure 1.Bp, Ba and Bs show the terpenoid test result of peel, aril and seed of oval shaped fruit. The peel gave the strongest purple colour (Fig. 1.Bp) than aril (Fig. 1.Ba) and seed (Fig. 1.Bs). The terpenoid test for peel of asymmetric shaped fruit, also shows the strongest purple colour (Fig. 2.Bp). For rounded shaped fruit, the terpenoid test shows that peel is only slightly different coloration than aril and seed).
For flavonoid test, all of three extracts of peels gave positive result indicated by yellow, orange to dark red or magenta coloration (Fig. 1.Cp, Fig. 2.Cp and Fig. 3.Cp). This secondary metabolite was not found on aril (Fig. 1.Ca, Fig. 2.Ca and Fig. 3.Ca) and seed (Fig. 1.Cs, Fig. 2.Cs and Fig. 3.Cs) of three fruit shapes due to no coloration presence. As well as terpenoid, saponin was found in all of nine tested sample. The saponin content can be observed by the presence of soapy foaming substance as seen on Figure 1.Dp, Figure 2.Dp and Figure 3.Dp. The tannin content was found in four samples i.e. peel extracts of three fruit shape (Fig. 1.Ep, Fig. 2.Ep, and Fig. 3.Ep), and seed extract of oval shaped fruit (Fig. 1.Es). The result of phytochemical contents of each sample is tabulated at Table 3. The higher number of secondary metabolite is 
found in peel of three different fruit shape, with a total of five compound (alkaloid, terpenoid, flavnoid, saponin and taninn). The similar secondary metabolite among the examined samples was also observed on aril. However, only two compound found in this part. i.e. terpenoid and saponin. The Seed of oval shaped fruit gave the highest number of secondary metabolite, with a total of four compounds ie. Alkaloid, terpenoid, saponin and tanin). On the other hand, only two compounds (terpenoid and saponin) were present in seed of asymmetric shaped fruit and rounded shaped fruit of $N$. maingayi.

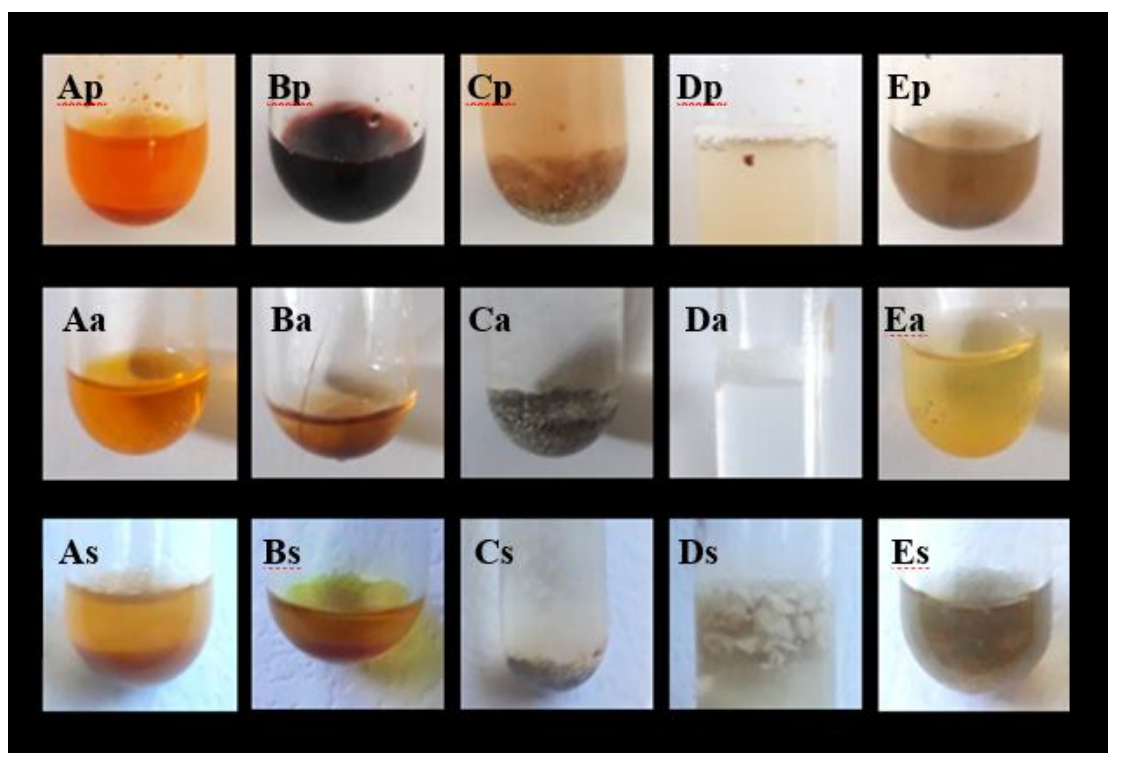

Figure 1. The phytochemical screening result of oval shaped fruit of Ridan (N. maingayi) (A=alkaloid, $\mathrm{B}=$ terpenoid and steroid, $\mathrm{C}=$ flavonoid, $\mathrm{D}=$ saponin, $\mathrm{E}=$ tannin, $\mathrm{p}=$ peel, $\mathrm{a}=$ aril, $\mathrm{s}=$ seed).

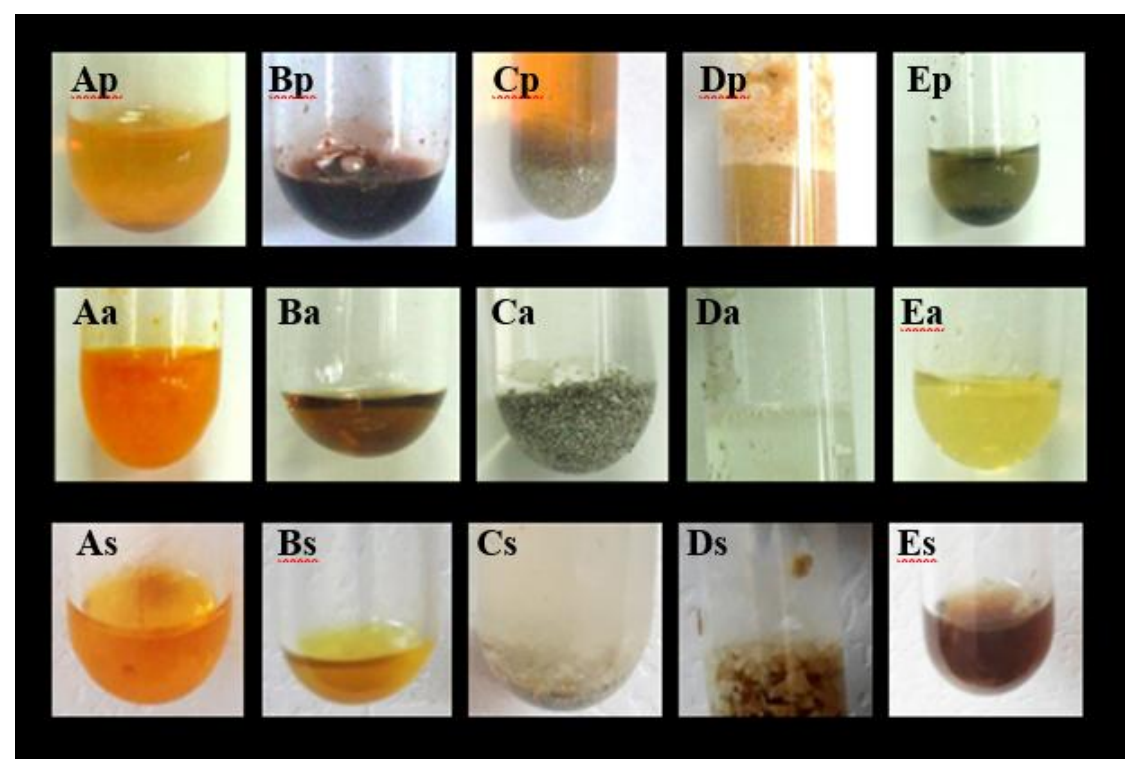

Figure 2. The phytochemical screening result of asymmetric shaped fruit of Ridan (N. maingayi) $(\mathrm{A}=$ alkaloid, $\mathrm{B}=$ terpenoid and steroid, $\mathrm{C}=$ flavonoid, $\mathrm{D}=$ saponin, $\mathrm{E}=\operatorname{tannin}, \mathrm{p}=$ peel, $\mathrm{a}=$ aril, $\mathrm{s}=$ seed $)$. 


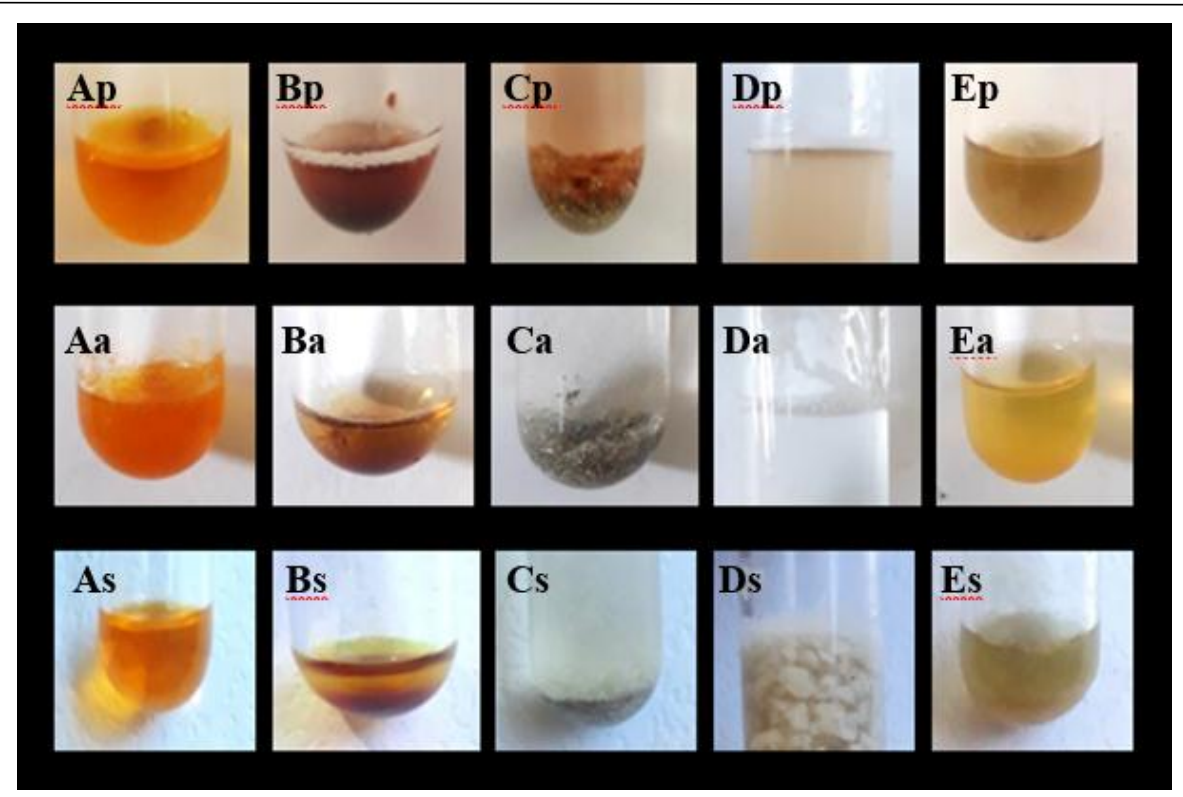

Figure 3. The phytochemical screening result of rounded shaped fruit of Ridan (N. maingayi) $(\mathrm{A}=$ alkaloid, $\mathrm{B}=$ terpenoid and steroid, $\mathrm{C}=$ flavonoid, $\mathrm{D}=$ saponin, $\mathrm{E}=\operatorname{tannin}, \mathrm{p}=$ peel, $\mathrm{a}=\operatorname{aril}, \mathrm{s}=$ seed $)$.

Table 3. Phytochemical contents of Ridan (N. maingayi)

\begin{tabular}{|l|c|l|c|c|c|c|c|c|c|}
\hline \multicolumn{1}{|c}{ Fruit Characteristic } & $\begin{array}{c}\text { Sample } \\
\text { Codes }\end{array}$ & Organs & ALK & TER & STE & FLA & SAP & TAN & NSM \\
\hline \multirow{4}{*}{ A. Oval shaped fruit } & 1 & Peel & + & + & - & + & + & + & 5 \\
\cline { 2 - 10 } & 2 & Aril & - & + & - & - & + & - & 2 \\
\cline { 2 - 9 } & 3 & Seed & + & + & - & - & + & + & 4 \\
\hline \multirow{5}{*}{ B. Asymmetric shaped fruit } & 4 & Peel & + & + & - & + & + & + & 5 \\
\cline { 2 - 9 } & 5 & Aril & - & + & - & - & + & - & 2 \\
\cline { 2 - 9 } & 6 & Seed & - & + & - & - & + & - & 2 \\
\hline C. Rounded shaped fruit & 7 & Peel & + & + & - & + & + & + & 5 \\
\cline { 2 - 9 } & 8 & Aril & - & + & - & - & + & - & 2 \\
\cline { 2 - 9 } & 9 & Seed & - & + & - & - & + & - & 2 \\
\hline
\end{tabular}

Note: $\mathrm{ALK}=$ alkaloid, TER $=$ terpenoid, $\mathrm{STE}=$ steroid, FLA $=$ flavonoid, $\mathrm{SAP}=$ saponin, $\mathrm{TAN}=$ tannin, NSM $=$ number of secondary metabolite.

\section{Alkaloid}

Alkaloid is one of secondary metabolite that commonly present in plant group (Matsuura $\&$ Fett-Neto 2015). This group is an organic compound with nitrogen as basic component (Sangi et al. 2008). In plant, alkaloid plays an important rule on plant defense from herbivore and pathogen attack due to its toxicity (Ruby \& Sara. 2015; Matsuura \& Fett-Neto 2015). The presence of alkaloid in this study was known by the presence of precipitation with red or orange coloration. Alkaloid was found in four samples with sample code 1, 3, 4, and 7. Three samples
\end{abstract}

are the extracts of peel of oval (1), asymmetric (3) and rounded (7) shaped fruit, and one sample is seed extract of $N$. maingayi with oval shaped fruit (4). However, the precipitation of seed extract of oval shaped fruit of $N$. maingayi is thicker than peel extract as seen in Figure 1.As. This result indicates the high amount of alkaloid. The alkaloid test used Dragendroff reagent, and the coloration is present due to the reaction of potassium bismuth iodide (Kumar 2014). The presence of alkaloid compound was reported on N. lappaceum (Nethaji et al. 2017). 


\section{Terpenoid and steroid}

The tests of terpenoid and steroid were carried together, using Lierman Bauchard reagent that contain $\mathrm{H}_{2} \mathrm{SO}_{4}$ and Anhydrate acetic acid (Malik \& Ahmad 2017). The presence of terpenoid indicated by orange to purple coloration, while steroid by green to blue coloration (Sangi et al. 2008; Raman et al. 2018). Terpenoid is large organic chemical in plant that derived from terpene. Plant with terpenoid content has potency as antimicrobial, antioxidant, anticancer and as well as nerf protection (Malik \& Ahmad 2017). Steroid is a secondary metabolite of terpenoid group. It functions to increase the growth hormone and protect plant from insect, as well as antiinflammatory agent (Patel \& Savjani 2015). In this study, all of the tested samples showed positive result of terpenoid, due to the presence of orange to purple coloration of the extracts as shown in Figure 1, 2, and 3 (Bp, Ba, Bs). However, the high amount of terpenoid was found on peel extract of three different fruit (Fig. 1.Bp, 2.Bp and 3.Bp), that showed dark purple coloration. In contrast, steroid is not found in all of the tested samples.

\section{Flavonoid}

Flavonoid is a bioactive compound from phenol group that also commonly found in plant (Panche et al. 2016). The presence of flavonoid indicated by the yellow, orange to dark red and magenta coloration (Sangi et al. 2008; Ruby \& Sara 2014). The coloration of flavonoid test is due to the reduction of magnesium and HCL (Robinson 1995). The function of flavonoid in plant is to support the transport of auxin hormone. Root and stem growth as well as pollination (Weston \& Mathesius 2013). Flavonoid is also plays an important function in antibacterial activity (Xie et al. 2015), antifungal, anti-viral (Weston \& Mathesius 2013, anti-inflammation and also has anticancer activity (Panche et al. 2016)). In this study, flavonoid is only found of peel extracts of three different fruit shapes (Fig. 1.Cp, 2.Cp and 3.Cp). This compound is not presence on aril and seed extracts.

\section{Saponin}

Saponin is derived from latin word "sapo" or soap, due to the soapy active compound at the surface (Faizal \& Gellen 2013). The soapy foaming substance is present when the mixture is strongly shaken, because of colloidal solution in water. Saponin is glycoside, that can be found in some part of plant organ (Guclu-Ustundag \& Maaza 2007; Faizal \& Gellen 2013). Saponin can be used for pesticide, insecticide, molluscicide, fungicide and for foaming industry (Faizal \& Geelen 2013). All of nine samples that had been tested in this study showed the presence of saponin. However, the thickness of soapy foaming substance is different among the samples. The thick layer was observed on 4 samples, i.e. sample code 3 (seed extract of oval shaped fruit; Fig.1.Dp), 4 (peel extract of asymmetric shaped fruit; Fig. 2.Dp), 6 (seed extract of asymmetric shaped fruit; Fig. 2.Ds) and 9 (seed extract of rounded shaped fruit; Fig. 3.Ds). Therefore, these four extracts have higher amount of saponin than the rest extracts that showed thin layer of soapy foaming substance.

\section{Tannin}

Tannins are group of astringent, a polyphenol in plant that produce bitter taste (Ashok \& Uphadyaya 2012). Tannins can bind protein and other macromolecule in tanning process. (Constabel et al. 2014) and widely used for coloring of textile, animal skin product, food, cosmetic and paper (Kyund, 2018). The presence of tannin indicated by green or blue coloring. In this study, only four out of nine samples that indicate the presence of tannin, i.e. sample code 1 (peel extract of oval shaped fruit; Fig. 1.Ep.), 3 (seed extract of oval shaped fruit; Fig. 1.Es), 4 (peel extract of asymmetric shaped fruit; Fig.2.Ep) and 7 (peel extract of rounded shaped fruit; Fig. 3.Ep).

Based on the explanation above, the phytochemical contents of three fruit shapes of Ridan (N. maingayi) varies among the different shape of fruit. The fruit peels contain the highest phytochemical contents. A total of 5 secondary metabolites were identified in fruit peel, i.e. Alkaloid, terpenoid, flavnoid, saponin and tanin. Usually, these compounds are commonly found in medicinal plants, as reported by Dhandapani and Shabna (2008). Therefore, it is necessary to conduct further study on medicinal properties of $N$. maingayi, especially in fruit peel. The other Nephelium that had been reported its benefit is $N$. 
lappaceum (Rambutan) that contant high antioxidant activity (Fidrianny et al. 2015).

\section{Conclusion}

The phytochemical contents of three fruit shapes of Ridan (N. maingayi) varies among the different shapes of fruit. The fruit peels contain the highest phytochemical contents, ie. Alkaloid, terpenoid, flavonoid, saponin and tannin. This study provides the first information of bioactive profile of N. maingayi form Riau Province.

\section{Acknowledgement}

This study is funded by PDUPT research grant from DRPM KEMENRISTEK BRIN 2021, led by main author.

\section{References}

Ashok, P. K., \& Upadhyaya, K. (2012). Tannins are Astringent. Journal of Pharmacognosy and Phytochemistry 1(3): 45-50. DOI:https://www.phytojournal.com/vol1I ssue3/Issue_sept_2012/8.1.pdf.

Constabel, P. C., Yoshida, K., \& Walker, V. (2014). Diverse Ecological Roles of Plant Tannins: Plant Defense and Beyond. In Recent Advances in Polyphenol Research, 4( $1^{\text {st }}$ Edition), Chapter 5: John Wiley \& Sons. DOI:10.1002/9781118329634.ch5.

Dhandapani, R \& Sabna, B. (2008). Phytochemical constituents of some Indian medicinal plants. Asc. Sc. Life XXVII (4): 1-7. DOI: https://www.ncbi.nlm.nih.gov/pmc/article s/PMC3330865/

Deepa, G. M., Ruby, R., \& Sara, C. (2014). Preliminary phytochemichal Analysis of Pyrrosia lanceolata (L.) Farwell. International Research Journal of Pharmacy 5(12): 879-883. DOI: https://irjponline.com/admin/php/uploads/ 2270_pdf.pdf.

Faizal, A., \& Geelen, D. (2013). Saponins and their role in biological processes in plants.
Phytochem Rev. 12: 877-893. DOI: 10.1007/s11101-013-9322.

Fidrianny, I., Sari, P.I., \& Wirasutisna, K. R. (2015). Antioxidant Activities in Various Peel Extracts of Four Varieties Rambutan (Nephelium lappaceum) Using DPPH, FRAP. Assays International Journal of Pharmacognosy and Phytochemical Research 7(2): 280-285. DOI: https://innovareacademics.in/journals/ind ex.php/ajpcr/article/view/7350.

Guclu,-Ustundag, O., \& Mazza, G. 2007. Saponins: Properties, Applications and Processing. Critical Reviews in Food Science and Nutrition 47: 231-58. DOI: 10.1080/10408390600698197.

Halim, H.R., Hapsari, D. P., Junaedi, A., Ritonga, A.W., Natawijaya, A., Poerwanto, R., Sobir, Widodo, W.D., ... Matra, D.D. (2019). Metabolomics dataset of underutilized Indonesian fruits; rambai (Baccaurea motleyana), nangkadak (Artocarpus nangkadak), rambutan (Nephelium lappaceum) and Sidempuan salak (Salacca sumatrana) using GCMS and LCMS. Data in brief 23: 1-4. DOI: 10.1016/j.dib.2019.103706

Hock, E. K., Azrina, A., Sou, T. T., \& See, M. (2017). Limanthocyanidins and Anthocyanins: Colored Pigments As Food, Pharmaceutical Ingredients, and The Potential Health Benefits. Food Nutr Res, 61(1): 1-21. DOI: 10.1080/16546628.2017.1361779.

Jian, S., Hongxiang, P., Weiqiang, S., Jinyan, Y., Xing, L., \& Jubing, W. (2011). Anthocyanins extracted from rambutan (Nephelium lappaceum) pericarp tissues as potential natural antioxidants. Journal of Food Biochemistry 35(5): 1461-1467. DOI:10.1111/j.1745-4514.2010.00467.x.

Kong, K. W., Khoo, H. E., Prasad, K. N., Ismail, A., Tan, Chin., \& Rajab, N. (2010). Revealing the Power of the Natural Red Pigment Lycopene. Molecules 
(Basel,Switzerland), 15: 959-987. DOI: 10.3390/molecules 15020959 .

Kyung, H. H. (2018). Effects of tannin mordanting on coloring and functionalities of wool fabrics dyed with spent coffee grounds. Fashion and Textiles 5: 2-11. DOI: 10.1186/s40691-018-0151-3.

Malik, S.K., \& Ahmad, M.K.F. (2017). Qualtitative and Quantitative Estimation Of Terpenoid Contents In Some Important Plants Of Punjab, Pakistan. Pakistan Journal of Science 69(2): 150-154. DOI:htps://www.thefreelibrary.com/qualt itative+and+quantitative+estimation $+\mathrm{of}+\mathrm{t}$ erpenoid+contents+in...-a0497857374

Matsuura H.N., \& Fett-Neto A.G. (2015). Plant Alkaloids: Main Features, Toxicity, and Mechanisms of Action. In: Gopalakrishnakone P., Carlini C., Ligabue-Braun R. (eds) Plant Toxins. Toxinology. Springer, Dordrecht. https://doi.org/10.1007/978-94-0076728-7_2-1.

Muhtadi, Suhendi, A., \& Wikantyasning, E.R. (2017). Gel Nanoemulsion of Rambutan (Nephelium Lappaceum L.) Fruit Peel Extracts: Formulation, Physical Properties, Sunscreen Protecting, And Antioxidant Activity. Asian Journal of Phramaceutical and Clinical Research 10(11): 220-224. DOI:10.22159/Ajpcr.2017.V10i11.19787

Nethaji, R., Thooyavan, G., Mullai, N.K., \& Ashok, K. (2015). Phytochemical Profiling, Antioxidant and Antimicrobial Activity Of Methanol Extract In Rambutan Fruit (Nephelium Lappacium) Epicarp Against The Human Pathogens. International Journal of Current Innovation Research, 1(9): 201-206. DOI: https://www.scribd.com/document/47573 2115/00200.

Panche, A.N., Diwan, A.D., \& Chandra, S.R. (2016). Flavonoid: an overview. J Nutr Sci. $\quad$ 5(47): $1-15$. DOI: $10.1017 /$ jns.2016.41.
Patel, S.S., \& Savjani, J.K. (2015). Systematic review of plant steroids as potential antiinflammatory agents: Current status and future perspectives. The Journal of Phytopharmacology 4(2): 121-125. DOI: http://www.phytopharmajournal.com/Vol 4_Issue2_12.pdf.

Raman, V., Rana, A., \& Sarma, A. (2018). Phytochemical Analysis \& Anthelmintic Activity of Leaves of Leucaena Leucocephala. World Journal of Pharmaceutical Research 7: 822-833. DOI: 10.20959/wjpr201811-12411.

Robinson, T. (1995). Kandungan Organik Tumbuhan Tinggi. Bandung: Penerbit ITB.

Sangi, M, Runtuwene, M. R. J., Simbala, H. E. I., \& Makang, V. M. A. (2008). Analisis Fitokimia Tumbuhan Obat Di Kabupaten Minahasa Utara. Chem. Prog, 1(1): 47-53. DOI:https://ejournal.unsrat.ac.id/index.ph p/chemprog/article/view/26.

Sukmandari, N. S., Dash, G. K., Jusof, W. H. W., \& Hanafi, M. (2017). A Review on (Nephelium lappaceum) L. Research $J$. Pharm. and Tech. 10(8): 2819-2827. DOI: 10.5958/0974-360X.2017.00498.X.

Weston, A. L., \& Mathesius, U. (2013). Flavonoids: Their Structure, Biosynthesis and Role in the Rhizosphere, Including Allelopathy. Journal of Chemical Ecology 39: 283-287. DOI: 10.1007/s10886-0130248-5. 